\title{
Inhalt/Table of Contents
}

Mathias Wirth, Isabelle Noth und Silvia Schroer

Sexualisierte Gewalt und das Problem kirchlicher Separatwelten

Eine Hinführung - 1

\section{Kontexte sexualisierter Gewalt}

Contexts of Sexual Violence

Melanie Werren

Sexualisierte Gewalt gegen Kinder und Jugendliche im kirchlichen Kontext Ein Überblick und eine Fallanalyse - 29

Rocío Figueroa and David Tombs

Living in Obedience and Suffering in Silence

The Shattered Faith of Nuns Abused by Priests - 45

Daniel J. Fleming

Overcoming Silence

Fraternal Correction, Hierarchy, and the Abuse Crisis in the Australian Catholic Church — 75

Regina Spiess

Sexuelle Gewalt gegen Kinder in der Gemeinschaft der Zeugen Jehovas als Ausdruck gesellschaftlich geduldeter Gewaltstrukturen -93

\section{Grundlegende Perspektiven \\ Fundamental Perspectives}

Gerhard Schreiber

Begriffe vom Unbegreiflichen

Beobachtungen zur Rede von „sexueller Gewalt“ und „sexualisierter Gewalt“ — 123 
Udo Rauchfleisch

Psychologische Aspekte der sexualisierten Gewalt im kirchlichen Kontext und ihre Folgen -147

Maren Behrensen

Die „Aufarbeitung“ der Missbrauchsskandale in der katholischen Kirche als hermeneutisches Unrecht 159

Alexander Fischer

Das Handwerk der Verführung Manipulation, Sexualität und Glaube - 189

Bastian König

Erfahrungen sexualisierter Gewalt verstehen?

Eine hermeneutische Spur im Ausgang von Paul Ricœurs Konzeption einer narrativen Identität $\longrightarrow \mathbf{2 1 5}$

Vincent Lloyd

The Phenomenology of Abuse

Lessons from Samuel Beckett -235

\section{Biblische und kirchenhistorische Perspektiven} Biblical and Church Historical Perspectives

Ilse Müllner

Frightening Continuities

Reading Stories on Sexual Violence in the Book of Samuel

Today 251

Susanne Scholz

Sexual Violence, Rape, and the Hebrew Bible

Reading Sexual Violence in the Bible after Two Thousand Years of

Silence - 267

Uwe Kaminsky

Tabuisierung und Gewalt

Sexualisierte Gewalt in der konfessionellen Heimerziehung der 1950er- und 1960er-Jahre — 285 


\section{Ethische Perspektiven}

\section{Ethical Perspectives}

Elisabeth Gräb-Schmidt

Der Abgrund menschlicher Möglichkeiten und der Anspruch des Anderen Theologisch-ethische Perspektiven zu sexualisierter Gewalt in kirchlichen Kontexten — 307

Reiner Anselm

Vertrauen - Konsens - Gemeinschaft

Über die Ambivalenzen zentraler Leitvorstellungen theologischer Ethik -327

Christoph Seibert

Menschenführung als Kontext sexualisierter Gewalt

Von der Ambivalenz einer unverzichtbaren Praxis - 335

Mathias Wirth

Die Banalisierung sexualisierter Gewalt im Gestus ihrer

Entschuldigung — 355

Hilary Jerome Scarsella

When Survivors Come Forward

Analyzing Patterns of Progressive Institutional Response and Working toward Transformative Interventions - 379

Susannah Cornwall

Sexual Abuse and the Interruption of Time, with Reference to the IICSA

Reports into Clerical Sexual Abuse within the Church of England - 405

\section{LGBTIQ und sexualisierte Gewalt in kirchlichen Kontexten} LGBTIQ and Sexual Violence in Church Contexts

Micah Cronin

On Brokenness

The Tension of LGBTQ Christians' Experiences of Sexual Abuse and Violence -425 
X Inhalt/Table of Contents

Livia Prüll

Von geschlechtsbezogener Gewalt zur „Reformation für Alle*“

Die christlichen Kirchen in Deutschland und

Transsexualität/Transidentität - $\mathbf{4 4 5}$

Jasmin Mannschatz

„We were expected to carry the weight of their shame and guilt, thinking it was our shame."

Gerard Rodgers' sozialethisches Prinzip mea culpa im Kontext sexualisierter Gewalt $\mathbf{4 7 9}$

\section{Praktisch-theologische Perspektiven} Practical Theological Perspectives

Isabelle Noth

Mythical Self-Conceptions in Spiritual Care -503

Mary Clark Moschella

Patriarchy, Power, and Bodies

A Pastoral Theological View of Sexual Abuse in the Church $-\mathbf{5 0 9}$

Joyce Ann Mercer

Spiritual Care for Survivors of Church-Related Sexual Abuse

Making the Case for Moral Injury — $\mathbf{5 2 1}$

Isabelle Noth

Poimenische Reflexionen zu sexualisierter Gewalt an Minderjährigen im kirchlichen Kontext 5337

Autor*innenverzeichnis/List of Contributors - 545

Register -551 